\title{
PENINGKATAN IMPLUSE BUYING PADA WANITA BEKERJA DI JAWA TENGAH
}

\author{
Rahmi Yuliana, Himawan Arif Sutanto \\ STIE BPD \\ rahmiyulia1978@gmail.com
}

\begin{abstract}
Knowledge about consumers is the key to planning a marketing strategy in the company, the customer can be the most valuable asset so the company needs to maintain and create equity. The development of technology is very rapid from the development of new product markets to meet the increasing needs of society as well. business people lead to the establishment of many shopping facilities that offer services and facilities that make it easier, then this can attract consumers. Impulsive buying and unplanned buying by some researchers are not differentiated. Semuel, (2005) does not distinguish between unplanned buying and impulsive buying but gives important attention to researchers, customers must focus on the interaction between point of sale with buyers who are often ignored. Personal selling is a form of individual communication where a salesperson deals directly with potential buyers and tries to influence them to buy their products or services. Hedonic shopping according to Semuel (2005) reflects an instrument that directly presents the benefits of experience in spending, such as pleasure, new things. Multiple Linear Regression Analysis is used to analyze the effect of several independent or independent variables $(X)$ on one dependent or dependent variable $(Y)$ together.
\end{abstract}

Keywords: Impulse buying, personal selling, hedonic shopping value, lemongrass atmosphere

\begin{abstract}
ABSTRAK
Pengetahuan tentang konsumen merupakan kunci dalam merencanakan suatu strategi pemasaran pada perusahaan, pelanggan dapat menjadi asset yang paling berharga sehingga perusahaan perlu menjaga sekaligus menciptakan ekuitas tersebut.Perkembangan teknologi yang sangat pesat dari berkembangnya pasar produk baru untuk memenuhi kebutuhan masyarakat yang terus meningkat pula, strategi pemasaran pelaku bisnis mengarah pada banyak berdirinya sarana belanja yang menawarkan pelayanan serta fasilitas yang memudahkan, yang kemudian hal ini dapat menarik konsumen,

Pembelian impulsif (impulsive buying) dan pembelian tidak direncanakan (unplanned buying) oleh beberapa peneliti tidak dibedakan.Semuel, (2005) tidak membedakan antara unplanned buying dengan impulsive buying, tetapi memberikan perhatian penting kepada periset, pelanggan harus memfokuskan pada interaksi antara point-of-sale dengan pembeli yang sering diabaikan. Personal selling adalah bentuk komunikasi orang perorang dimana seseorang wiraniaga berhubungan langsung dengan calon pembeli dan berusaha mempengaruhi agar mereka membeli produk atau jasanya. Hedonic shopping menurut Semuel (2005) mencerminkan instrumen yang menyajikan secara langsung manfaat dari suatu pengalaman dalam melakukan pembelanjaan, seperti kesenangan, hal-hal baru.

Analisis Regresi Linier Berganda digunakan untuk menganalisa pengaruh beberapa variabel bebas atau independen variabel $(\mathrm{X})$ terhadap satu variabel tidak bebas atau dependen variabel (Y) secara bersama-sama.
\end{abstract}

Kata kunci : Impluse buying, personal selling, hedonic shopping value, atmosfer serai 


\section{PENDAHULUAN}

\section{Latar Belakang Masalah}

Pengetahuan tentang konsumen merupakan kunci dalam merencanakan suatu strategi pemasaran pada perusahaan, pelanggan dapat menjadi asset yang paling berharga sehingga perusahaan perlu menjaga sekaligus menciptakan ekuitas tersebut. Perkembangan teknologi yang sangat pesat dari berkembangnya pasar produk baru untuk memnuhi kebutuhan masyarakat yang terus meningkat pula, strategi pemasaran pelaku bisnis mengarah pada banyak berdirinya sarana belanja yang menawarkan pelayanan serta fasilitas yang memudahkan, yang kemudian hal ini dapat menarik konsumen, wanita karier adalah salah satu sebutan dari pihak wanita bekerja yang pada umumnya melakukan pekerjaan diluar rumah atau berkiprah di sektor public dan biasanya bkerja pada sektor instansi, baik usaha, perkantoran dan sebagainya. Wanita karier memiliki target jabatan atau jenjang karier tertentu dengan bekal pendidikan yang telah dicapai. Wanita karier mempunyai kemampuan dalam mengelola keuangan individu, yang mana slain untuk memenuhi kebutuhan keluarga juga untuk mmemenuhi kebutuhan pribadinya.Wanita karier atau pekerja di sektor public membutuhkan busana dan aksesoris untuk mendukung penampilan mereka mendukung penampilan mereka yang merupakan hal penting yang harus diperhatikan. Pada umumnya wanita karier produktif memiliki kisaran umur yaitu antara usia 20 - 40 tahun.

Dalam sebuah bsinis promosi sangat diperlukan untuk menginformasikan dan mempengaruhi pendapat konsumen agar membeli sehingga menaikkan volume penjualan.Untuk strategi promosi sangat penting dilakukan. Salah satu alat promosi adalah personal selling. Personal selling merupakan kegiatan perusahaan untuk melakukan kontak langsung dengan konsumennya yang diharapkan akan menimbulkan interaksi yang positif antara perusahaan dan konsumen untuk membujuk konsumen membeli dan merangsang impulse buying.

Impluse buying dapat didasari oleh factor individu konsumen yang berperilaku efektif, perilaku ini kemudian membuat pelanggan memiliki pengalaman berbelanja.Pengalaman ini dapat dikelompokkan menjadi hedonic shopping value. Menurut Hausman (2000) Kim and Forny (2005) Hedonic shopping value memainkan peean yang cukup penting dalam impulse buying, oleh karena itu seringkali konsumen mengalami impulse buying ketika didorong oleh keinginan hedonis atau pengaruh emosional. Ketika berbelanja seseorang menjad tujuan untuk memenuhi kepuasan kebutuhan yang bersifat hedonic maka produk yang dipilih untuk dibei bukan berdasarkan rencana awal ketika menuju toko tersebut, melainkan karena impulse 
buying yang disebabkan oleh pemenuhan kebutuhan yang bersifat hedonisme ataupun karena emosi positif.

\section{MASALAH PENELITIAN}

1. Apakah personal selling berpengaruh terhadap impulse buying

2. ApakahHedonis shopping value berpengaru terhadap impulse buying

3. Apakah Atmosfer Gerai berpengaruh terhadap impulse buying.

\section{KAJIAN TEORITIS}

\section{Impluse Buying}

Pemahaman tentang konsep pembelian impulsif (impulsive buying) dan pembelian tidak direncanakan (unplanned buying) oleh beberapa peneliti tidak dibedakan. Semuel, (2005) tidak membedakan antara unplanned buying dengan impulsive buying, tetapi memberikan perhatian penting kepada periset, pelanggan harus memfokuskan pada interaksi antara point-of-sale dengan pembeli yang sering diabaikan. Impulse buying pada produk convenience good yaitu barang yang dibutuhkan konsumen dan dibeli tanpa menyediakan banyak waktu.Barang ini sering tidak memerlukan layanan, tidak mahal dan biasaya dibeli karena kebiasaan.

Semuel, (2005) mendefinisikan unplanned buying adalah suatu tindakan pembelian yang dibuat tanpa direncanakan terlebih sebelumnya atau keputusan pembelian dilakukan pada saat berada di dalam toko. Semuel, (2005) juga mengklasifikasikan suatu pembelian impulsif terjadi apabila tidak terdapat tujuan pembelian merek tertentu atau kategori produk tertentu pada saat masuk ke dalam toko. Loudon dan Bitta (1998) menyatakan "Impulse buying or unplanned purchasing is another specifically planned". Ini berarti bahwa impulse buying merupakan salah satu jenis perilaku konsumen, dimana hal tersebut terlihat dari pembelian konsumen yang tidak secara rinci terencana.

Iyer (1989) menyatakan impulse buying adalah suatu fakta kehidupan dalam perilaku konsumen yang dibuktikan sebagai suatu kegiatan pembelian yang berhubungan dengan lingkungan dan keterbatasan waktu dalam berbelanja, dimana rute pembelian yang mereka lakukan semestinya berbeda. Rute tersebut dapat dibedakan melalui hirarki impulse yang memperlihatkan bahwa perilaku didasarkan pada respon afektif yang dipengaruhi oleh perasaan yang kuat (Mowen dan Minor, 2002), sehingga impulse buying, terjadi ketika terdapat perasaan positif yang sangat kuat yang kemudian diikuti oleh sikap pembelian. 
Hausman (2000) mengatakan bahwa unplanned buying berkaitan dengan pembelian yang dilakukan tanpa ada perencanaan dan termasuk impulse buying yang dibedakan oleh kecepatan relatif terjadinya keputusan pembelian. Adapun tipe-tipe dari pembelian tidak terencana menurut Loudon, David dan Della Bitta Albert (1998):

$1 \quad$ Pure Impulse (pembelian Impulse murni). Sebuah pembelian menyimpang dari pola pembelian normal. Tipe ini dapat dinyatakan sebagai novelty / escape buying.

2. Suggestion Impulse (Pembelian impuls yang timbul karena sugesti). Pembelian tipe ini, konsumen tidak mempunyai pengetahuan yang cukup terlebih dahulu tentang produk baru, konsumen melihat produk tersebut untuk pertama kali dan memvisualkan sebuah kebutuhanuntuk benda tersebut.

3. Reminder Impulse (pembelian impulse karena pengalaman masa lampau) Pembeli melihat produk tersebut dan diingatkan bahwa persediaan dirumah perlu ditambah atau telah habis.

4. Planned Impulse (Pembelian impulse yang terjadi apabila kondisi penjualan tertentu diberikan) .Tipe pembelian ini terjadi setelah melihat dan mengetahui kondisi penjualan.Misalnya penjualan produk tertentu dengan harga khusus, pemberian kupon dan lain-lain.

Engel, Blackwell, dan Miniard (1993), menyatakan bahwa suatu pembelian dapat direncanakan dalam suatu pengertian walaupun niat yang pasti tidak dinyatakan secara verbal atau secara tertulis pada daftar belanja. Berdasarkan penelitian Rook dan Fisher (1995), bahwa pembelianbardasarkan impulse terjadi ketika konsumen mengalami desakan tiba-tiba, yang biasanya sangat kuat dan menetap untuk membeli sesuatu dengan segera.

\section{Personal Selling}

Personal selling adalah bentuk komunikasi orang perorang dimana seseorang wiraniaga berhubungan langsung dengan calon pembeli dan berusaha mempengaruhi agar mereka membeli produk atau jasanya. Personal selling adalah presentasi lisan dalam suatu percakapan dengan calon pembeli atau lebih yang dutujukan untuk menciptakan penjualan. Personal selling (penjualan pribadi) adalah suatu penyajian (presentasi) suatu produk kepada konsumen akhir yang dilakukan oleh tenaga penjual perusahaan yang representatif. Personal selling melibatkan interaksi personal langsung antara seorang pembeli potensial dengan seorang salesman. 
Penjualan personal dapat menjadi metode promosi yang hebat untuk paling tidak untuk dua alasan, yaitu :

a. Komunikasi personal dengan salesman dapat meningkatkan keterlibatan konsumen dengan produk dan atau proses pengambilan keputusan. Oleh karena itu konsumen dapat lebih termotivasi untuk masuk dan memahami informasi yang disajikan salesman tentang suatu produk.

b. Situasi komunikasi saling / interaktif memungkinkan salesman mengadaptasi apa yang disajikannya agar sesuai dengan kebutuhan informasi setiap pembeli potensial. Beberapa produk konsumsi tertentu biasanya dipromosikan melalui penjualan personal seperti asuransi jiwa, mobil dan perumahan.

Manfaat Personal Selling. Personal selling adalah komunikasi langsung (tatap muka) antara penjual dan calon pelanggan untuk memperkenalkan suatu produk kepada calon pelanggan dan membentuk pemahaman pelanggan terhadap produk sehingga mereka kemudian akan mencoba dan membelinya. Personal Selling memiliki tiga manfaat sebagai berikut :

1 Personal confrontation, yaitu adanya hubungan yang hidup, langsung, dan interaktif antara 2 orang atau lebih.

2 Cultivation, yaitu sifat yang memungkinkan berkembangnya segala macam hubungan, mulai dari sekedar hubungan jual beli sampai dengan suatu hubungan yang lebih akrab.

3 Response, yaitu situasi yang seolah-olah mengharuskan pelanggan untuk mendengar, memperhatikan, dan menanggapi.

Tahapan Personal Selling. Personal selling merupakan kegiatan perusahaan untuk melakukan kontak langsung dengan konsumennya yang diharapkan akan menimbulkan interaksi yang positif antara perusahaan dan konsumen. Saat ini banyak pemilik merek menyediakan langsung SPG ke dalam toko untuk menawarkan langsung kepada konsumen dengan tujuan untuk membujuk konsumen membeli dan merangsang impulse buying. Menurut Kotler dan Keller, personal selling memiliki beberapa tahap yaitu mencari Calon Pelanggan Tahap pertama dalam penjualan adalah mengidentifikasi dan mengkualifikasikan calon pelanggan, semakin banyak perusahaan yang bertanggung jawab untuk mencari dan mengkualifikasikan petunjuk sehingga wiraniaga dapat menggunakan waktu mereka yang tidak.

H1 = Personal Selling berpengaruh positif terhadap impulse buying 


\section{Hedonic Shopping Value}

Hedonic shopping menurut Semuel (2005) mencerminkan instrumen yang menyajikan secara langsung manfaat dari suatu pengalaman dalam melakukan pembelanjaan, seperti kesenangan, hal-hal baru. Hedonic shopping merupakan nilai intrinsik yang lebih merefleksikan pengalaman keuntungan yang dinyatakan langsung sebagai pengalaman belanja. Beberapa penelitian menemukan arousal pelanggan berhubungan positif dengan hedonic shoping value, yang menjadikan lingkungan toko sebagai tempat yang menarik untuk menghabiskan waktu luang (Babin,et al.,1995).

Konsumsi hedonis meliputi aspek tingkah laku yang berhubungan dengan multysensory, fantasi dan konsumsi emosional yang dikendalikan oleh manfaat seperti kesenangan dalam menggunakan produk dan pendekatan estetis (Hirschman dan Holbrook,1982).Tawar dan menawar adalah dua pengalaman berbelanja berhubungan dengan kenikmatan dalam berbelanja (Sherry,1990), oleh karena itu disarankan bahwa pengalaman pembelian mungkin adalah lebih penting dibanding memenuhi keinginan hedonis berhubungan dengan konsumsi hedonis (Hausman,2000; Piron (1991), Rook,1987 dalam Park,Kim and Forney,(2005)). Peran ini mendukung hubungan konseptual antara motivasi berbelanja hedonis dan perilaku impulse buying. Hal ini menunjukkan konsumen lebih mungkin terlibat dalam impulse buying ketika mereka termotivasi oleh keinginan hedonis atau alasan ekonomi, seperti kesenangan, fantasi, dan sosial atau kepuasan emosional. Sejak tujuan pengalaman berbelanja untuk mencukupi kebutuhan hedonis, produk yang akan dibeli ini nampak seperti terpilih tanpa perencanaan dan mereka menghadirkan suatu peristiwa impulse buying. Perilaku pembelian impulse buying pada orientasi fashion termotivasi oleh versi baru dari mode fashion dan citra merek yang memandu konsumen ke pengalaman berbelanja hedonis (Goldsmith dan Emmert,1991 dalam Park et al.,2005). Dibandingkan dengan aspek belanja utilitilarian, nilai hedonis "menyenangkan" menggembirakan, atau sisi gemar akan makanan dan minuman yang tidak banyak dipelajari. Nilai hedonis lebih subyektif dan personal daripada nilai utilitarian sebagai pertimbangan dan menghasilkan lebih dari senang dalam permainan daripada penyelesaian tugas (Hirschman dan Hoolbrook,1982). Maka, nilai belanja hedonis menggambarkan potensi hiburan berbelanja dan bernilai emosional (Bellenger,Steiberg dan Stanton,1976 dalam Babin dan Darden (1995).

\section{Emotions}

Menurut Park,et al.,2005 Emotions adalah sebuah efek dari mood yang merupakan faktor penting konsumen dalam keputusan pembelian. Secara tipikal, emosi diklasifikasikan menjadi 
dua dimensi ortogonal, yaitu positif dan negatif (Watson and Telegen,1985 dalam Park et al.,2005). Beberapa penelitian kualitatif melaporkan bahwa konsumen mengalami perasaan yang bersemangat dan bergairah dalam hidup setelah berbelanja (Bayley and Nancarrow, 1998; Dittmar et al.,1996;Rook,1987 dalam Park, Kim Forney,(2005)). Emosi positif dapat didatangkan dari sebelum terjadinya mood seseorang, kecondongan sifat afektif seseorang dan reaksi pada lingkungan yang mendukung seperti ketertarikan pada item barang ataupun adanya promosi penjualan.

\section{Emosi Positif}

Menurut Mehrabian dan Russel (1974) dalam Babin dan Darden (1995),menyatakan bahwa respon afektif lingkungan atas perilaku pembelian dapat diuraikan oleh 3 variabel yaitu : Pleasure, mengacu pada tingkat di mana individu merasakan baik, penuh kegembiraan, bahagia yang berkaitan dengan situasi tersebut. Pleasure diukur dengan penilaian reaksi lisan ke lingkungan (bahagia sebagai lawan sedih, menyenangkan sebagai lawan tidak menyenangkan, puas sebagai lawan tidak puas, penuh harapan sebagai lawan berputusasa, dan santai sebagai lawan bosan). Konseptualisasi terhadap pleasure dikenal dengan pengertian lebih suka, kegemaran, perbuatan positif. Arousal, mengacu pada tingkat di mana seseorang merasakan siaga, digairahkan, atau situasi aktif.Arousal secara lisan dianggap sebagai laporan responden, seperti pada saat dirangsang, ditentang atau diperlonggar.Beberapa ukuran non verbal telah diidentifikasi dapat dihubungkan dan sesungguhnya membatasi sebuah ukuran dari arousal dalam situasi sosial. Dominance, ditandai dengan laporan responden yang merasa dikendalikan sebagai lawan mengendalikan, mempengaruhi sebagai lawan dipengaruhi, terkendali sebagai lawan diawasi, penting sebagai lawan dikagumi,dominan sebagai lawan bersikap tunduk dan otonomi sebagai lawan dipandu. Menurut Donovan dan Rositter (1982) dalam Peter dan Olson (2005:250) menyatakan bahwa store atmosphere terutama melibatkan afeksi dalam bentuk emosi dalam toko yang mungkin tanpa disadari sepenuhnya oleh pelanggan ketika sedang berbelanja.

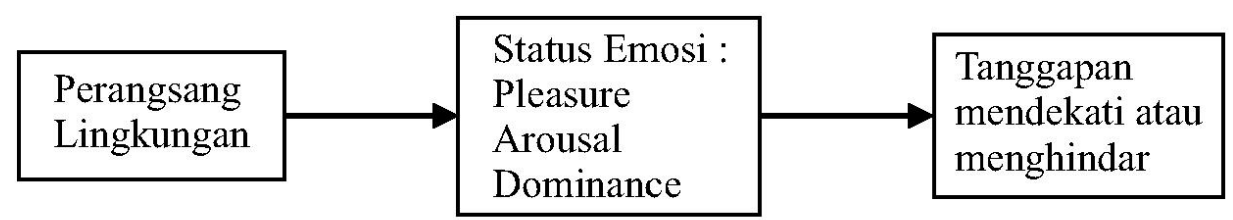

Gambar 1

Model dari Dampak Suasana Toko

Sumber : Donovan dan Rositter dalam Peter dan Olson (2005:251) 
Pada dasarnya, model tersebut menyatakanbahwa rangsangan lingkungan mempengaruhi status emosi pelanggan, yang mana padagilirannya akan mempengaruhi perilaku atau menjadi pelanggan. Perilaku mendekati adalah gerakan ke arah dan perilaku menghindar adalah gerakan menjauhi dari berbagaimacam lingkungan dan rangsangan.

Donovan dan Rositter (1982) meneliti hubungan antara ketiga status emosi yangditunjukkan pada Gambar 1 dan keinginan yang diungkapkan untuk melakukan perilakutertentu yang berkaitan dengan toko.Lingkungan ritel tertentu menimbulkan emosi di antara orang yang berbelanja dan bisadiringkas melalui tiga dimensi dasar pleasure, arousal dan dominance serta emosi iniadalah faktor penyebab yang menjelaskan perilaku konsumen dan pembuatan keputusan (Darden dan Babin,1994; Dawson et al.,1990; Donovan dan Rositter, 1982; Hui dan Bateson, 1991 dalam Park, Kim and Forney,(2005)). Orang yang berbelanja mengalamikesenangan yang relatif tinggi dan menggerakkan secara umum meluangkan waktu lebih di toko dan lebih berkeinginan untuk melakukan pembelian daripada yang tidak senang atau bagian yang tidak tergerak. Temuan dengan menurut dominance adalah lebih jelas tetapi kunci ketertarikan pada perilaku-perilaku ritel lain karena kaitan terdekat antara tata letak toko dan kontrol dari pergerakan orang yang berbelanja selama di toko.

$\mathrm{H} 2$ = Hedonic Shopping value berpengaruh positif terhadap Impluse buying

\section{Atmosfer Gerai}

Atmosfer gerai merupakan salah satu elemen bauran pemasaran ritel yang terkait dalam hal penciptaan suasana belanja.Atmosfer merupakan kunci dalam menarik dan membuat konsumen terkesan dengan pengalaman berbelanja di dalam gerai (Coley dan Burgess, 2003). Para penjual harus mampu mengelola atmosfer (suasana) dalam gerai sedemikian rupa sehingga tujuan meningkatkan kunjungan pelanggan, penjualan bertambah, dan merangsang citra positif pelanggan dapat tercapai. Utami (2010) menyatakan terdapat dua macam motivasi berbelanja yang menjadi perhatian penjual dalam menyediakan atmosfer dalam gerai yang sesuai. Pertama adalah kelompok yang berorientasi pada motif utilitarian yang lebih mementingkan aspek fungsional.

Meskipun demikian, kelompok tersebut minimal akan memilih gerai yang tertata baik, bersih, dan berpendingin udara. Daya tarik visual dan fasilitas tambahan bukan hal yang terlalu pentvisual merchandising, dan fasilitas-fasilitas yang lengkap menjadi faktor penentu 
keputusan konsumen dalam mengunjungi suatu gerai. Oleh karena itu, para penjual harus mendandani tempat belanja dengan semenarik mungkin.ing bagi konsumen.

Kelompok kedua adalah kelompok yang berorientasi rekreasi, faktor ambience, visual merchandising, dan fasilitas-fasilitas yang lengkap menjadi faktor penentu keputusan konsumen dalam mengunjungi suatu gerai. Oleh karena itu, para penjual harus mendandani tempat belanja dengan semenarik mungkin.

H3 = Atmosfer Gerai berpengaruh positif terhadap Impluse buying

Model Penelitian adalah sebagai berikut :

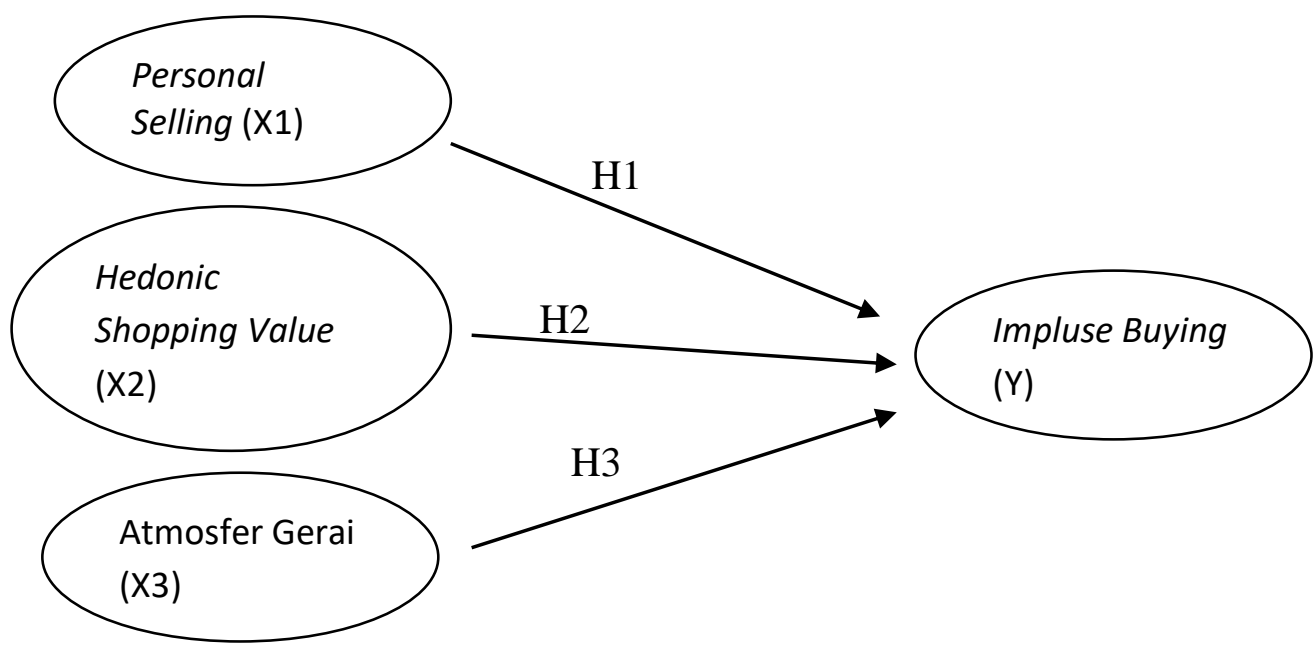

\section{METODOLOGI}

Penelitian ini menggunakan jenis penelitian field research (penelitian lapangan), penelitian studi kasus dan lapangan merupakan penelitian dengan karakteristik masalah yang berkaitan dengan latar belakang dan kondisi saat ini dari subyek yang diteliti, serta interaksinya dengan lingkungan.Subyek yang diteliti dapat berupa individu, kelompok, lembaga atau komunitas tertentu. Tujuan studi kasus adalah melakukan penyelidikan secara mendalam mengenai subyek tertentu untuk memberikan gambaran yang lengkap mengenai subyek tertentu. Lingkup penelitian kemungkinan berkaitan dengan suatu siklus kehidupan atau hanya mencakup bagian tertentu yang difokuskan pada faktor-faktor tertentu atau unsur-unsur dan kejadian secara keseluruhan.

Hasil dari penelitian kasus merupakan suatu generalisasi dari pola pola kasus yang tipikal dari individu, kelompok, lembaga dan sebagainya.Tergantung dari tujuannya, ruang 
lingkup dari studi dapat mencakup segmen atau bagian tertentu atau mencakup keseluruhan siklus kehidupan dari individu, kelompok, dan sebagainya, baik dengan penekanan terhadap faktor-faktor kasus tertentu ataupun meliputi keseluruhan faktor-faktor dan fenomenafenomena.Studi kasus lebih menekankan mengkaji variabel yang cukup banyak pada jumlah unit yang kecil. Penelitian ini ditujukan untuk memperoleh bukti empirik, menguji dan menjelaskan pengaruh Hedonis shopping value dan personal selling terhadap impulse buying.

\section{Populasi dan Sampel}

Populasi dan Sampel Populasi adalah wilayah generalisasi yang terdiri atas obyek atau subyek yang memiliki karakteristik tertentu yang kemudian ditetapkan oleh peneliti untuk dipelajari dan ditarik kesimpulannya.Dalam penelitian ini populasi yang digunakan adalah seluruh pengunjung yang pernah melakukan pembelian terhadap suatu produk di Mall se Jawa Tengah. Teknik sampling yang digunakan di dalam penelitian ini adalah qutoa sampling, dimana menurut Notoatmodjo (2002 : p. 89), pengambilan sampel dilakukan dengan cara menetapkan sejumlah anggota sampel secara qutoa atau jatah. Sampel yang ditentukan dalam penelitian ini adalah adalah orang orang yang pernah berbelanja di Mall yang ada di Jawa Tengah dalam kurun waktu enam bulan terakhir. Penelitian ini menggunakan sampel sebanyak 200 responden, dengan berdasarkan pada pertimbangan tingkat keyakinan 0,95 dengan $\alpha 0,05$ dan kesalahan yang mungkin terjadi tidak lebih dari $10 \%$.

Definisi Operasional Variabel yang digunakan dalam penelitian ini yaitu:

1. Varibel Terikat yaitu Impluse buying (Y) dengan dimensi :

- Spontanitas pembelian

- Tidak mempertimbangan konsukensi

- Tidak dapat menolak keinginan

- Kuantitas pembelian

2. Variabel bebas atau variabel eksogen, yaitu

$\mathrm{X} 1=$ Hedonic Shopping Value $(\mathrm{X})$ dengan dimensi:

- Adventure Shopping adalah perasaan adanya tantangan dan suatu sensasi yang menggembirakan saat memasuki lingkungan yang menurutnya menyenangkan.

- Social Shopping adalah ketika berbelanja, seseorang menginginkan adanya keadaan 


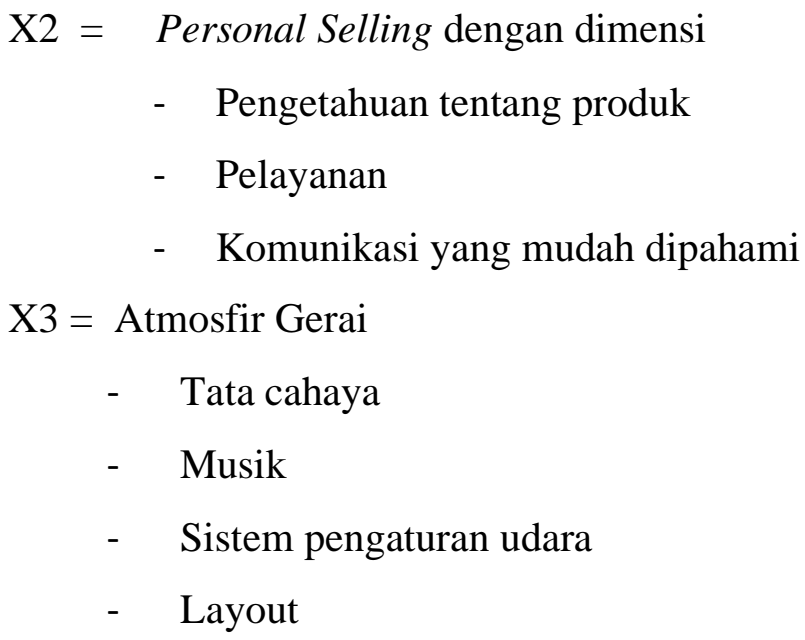

Analisis Regresi Linier Berganda

Analisis Regresi Linier Berganda digunakan untuk menganalisa pengaruh beberapa variabel bebas atau independen variabel $(\mathrm{X})$ terhadap satu variabel tidak bebas atau dependen variabel (Y) secara bersama-sama. Formula untuk regresi linier berganda sebagai berikut:

$$
\mathrm{Y} 1=\mathrm{b} 1 \times 1+\mathrm{b} 2 \times 2+\mathrm{e} \mathrm{Y} 2=\mathrm{b} 1 \times 1+\mathrm{b} 2 \times 2+\mathrm{b} 3 \times 3+\mathrm{e}
$$

Keterangan :

$$
\begin{aligned}
& \mathrm{Y}=\text { Impulse buying }(\mathrm{Y}) \\
& \beta 1=\text { Koefisien regresi untuk variabel Hedonis shopping value } \\
& \beta 2=\text { Koefisien regresi untuk variable Personal selling } \\
& \beta 3=\text { Koefisien Regresi untuk variabel Atmosfer Gerai } \\
& \mathrm{E}=\text { Kesalahan Estimasi Standar (error) }
\end{aligned}
$$

\section{PEMBAHASAN}

Sebelumnya dilakukan uji asumsi klasik yaitu normalitas, heteroskedastisitas, serta multikolinearitas. Pengujian menggunakan One sample Kolmogorov-Smirnov test mendapatkan nilai asymp.sig sebesar 0,320>0,05 yang artinya data berdistribusi normal. Hasil uji multikolinearitas mendapatkan nilai VIF kurang dari $10(1.590 ; 1.798 ; 1.402)$ serta Tolerance lebih dari $0,1(0.629 ; 0.556 ; 0.713)$ yang menunjukkan variabel bebas tidak terdapat multikolinearitas. Pengujian heteroskedastisitas menggunakan scatter plot yang menunjukkan titik - titik menyebar di atas maupun dibawah garis sehingga tidak terdapat masalah heteroskedastisitas.

Uji simultan mendapatkan nilai F sebesar 203,136 dengan signifikansi 0,000. Hasil ini menunjukkan bahwa personal selling, hedonic shopping, atmosfer gerai, berpengaruh secara simultan terhadap kinerja bisnis. Nilai koefisien determinasi sebesar 0,728 menunjukkan 
bahwa kinerja bisnis dipengaruhi oleh orientasi kewirausahaan, orientasi pasar serta strategi bisnis sebesar $72.8 \%$, sedangkan $27.2 \%$ dipengaruhi oleh faktor lain.

Pengujian secara parsial mendapatkan nilai signifikansi untuk personal selling, hedonic shopping, atmosfer gerai kurang dari 0,05. Hasil ini menunjukkan bahwa personal selling, hedonic shopping value serta atmosfer gerai secara parsial berpengaruh signifikan terhadap impluse buying

coefficients $^{\mathrm{a}}$

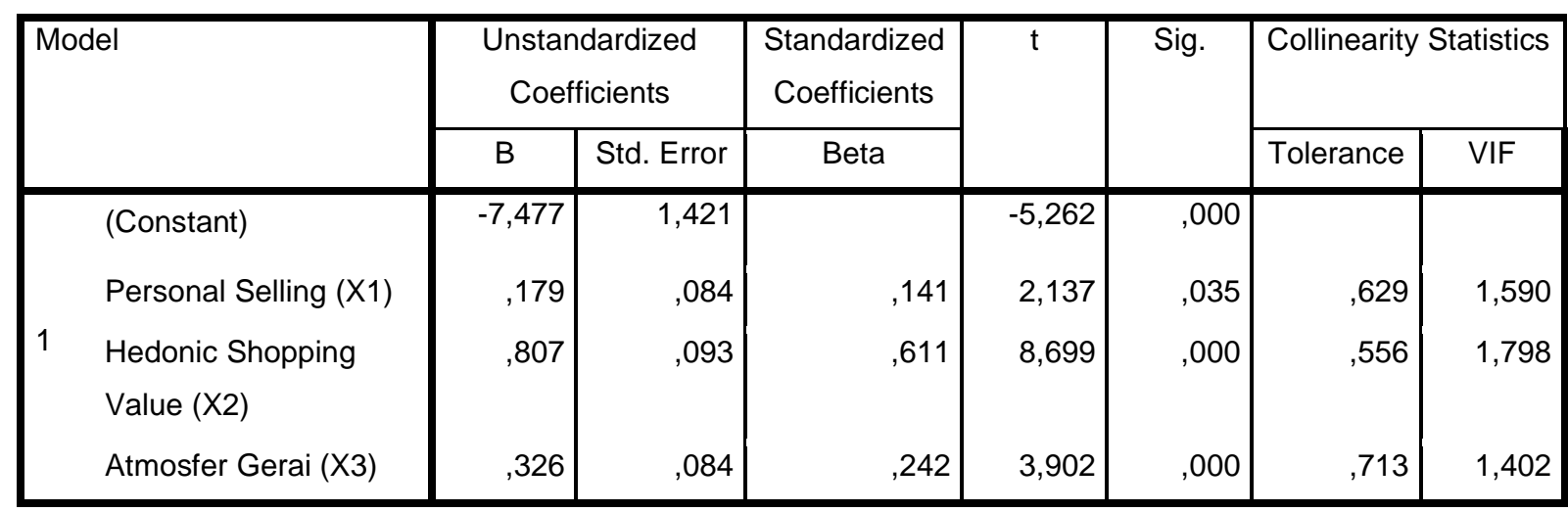

a. Dependent Variable: Impulse Buying (Y)

Penelitian responden terdapat variabel impluse buying pada penelitian ini dapat dilihat bahwa variabel hedonic shopping value mempunyai pengaruh yang paling besar sebesar 0.807 hal ini menunjukan bahwa pembelian secara tiba tiba yang dilakukan oleh konsumen didorong oleh perilaku yang didorong oleh panca indra, khayalan dan emosi yang menjadikan kesenangan dan kenikamatan materi sebagi tujuan utama hidup mereka, Kemudian variabel atmosfer gerai merupakan vairabel yang kedua dalam mempengaruhi impluse buying sebesar 0.326 hal ini menunjukan bahwa atmosfer gerai mempunyai peran penting dalam memikat kosumen, dalam berbelanja dan mengingatkan mereka produk apa yang sesuai dengan kepribadian mereka, serta vaiabel personal selling sebesar 0.197 hal ini menunjukan bahwa penjualan tatap muka bisa mempengaruhi pembelian dengan memperkenalkan produk kepada calon pembeli dalam impluse buying.

Hasil pengujian hipotesis mendapatkan bahwa hedonik shopping value berpengaruh positif terhadap impluse buying. Hasil ini sesuai dengan Hirchman dan Holbrook bahwa konsumsi hedonic meliputi aspek tingkah laku, fantasi dan konsumsi emosional yang dikendalikan oleh manfaat kesenangan dalam menggunakan produk, 
Hasil pengujian hipotesis mendapatkan bahwa atmosfer gerai berpengaruh positif terhadap impluse buying. Para penjual harus mampu mengelola atmosfer dalam gerai sedemikian rupa sehingga mampu meningkatkan kunjungan pelanggan, penjualan bertambah dan merangsang citra positif pelanggan dapat tercapai.

Hasil pengujian mendapatkan bahwa personal selling berpengaruh positif terhadap impluse buying. Hasil ini sesuai dengan Kotler dan Keller. Penjual harus mampu mencari calon pelanggan dalam tahap penjualan dan bertanggung jawab terhadap penelitian.

\section{KESIMPULAN}

Berdasarkan hasil analisis dan pembahasan maka didapat kesimpulan berikut ini:

1. Personal selling terbukti berpengaruh positif terhadap impluse buying. Disini dapat dijelaskan bahwa personal sellingadalah bagaimana penjual melakukan komunikasi dengan konsumen sehingga dapat mempengaruhi untuk membeli. Sehingga personal selling akan mempengaruhi impluse buying.

2. Hedonic Shopping Value berpengaruh positif terhadap impluse buying. Disini dapat dijelaskan bahwa hedonic shopping value adalah bagaimana aspek tingkah laku, fantasi dapat mempengaruhi pembelian. Sehingga hedonic shopping value akan mempengaruhi impluse buying.

3. Atmosfer gerai berpengaruh positif terhadap impluse buying. Disini dapat dijelaskan bahwa penjual harus mampu mengelola atmosfer gerai sedemikian rupa sehingga mampu meningkatkan kunjungan pelnggan.

\section{DAFTAR PUSTAKA}

Augusty Ferdinand, 2006. Metode Penelitian Manajemen, BPFE Universitas Diponegoro, Semarang,

Denny Kurniawan dan Yohanes Sondang, 2013. Pengaruh Promosi Dan Store Atmosphere Terhadap Impulse Buying Dengan Shopping Emotion Sebagai Variabel Intervening Studi Kasus Di Matahari Department Store Cabang Supermall Surabaya, Jurnal Manajemen Pemasaran Petra, Vol. 1, No. 2

Devi Kurniawati dan Sri Restuti, 2014. Pengaruh Sales Promotion Dan Store Atmosphere Terhadap Shopping Emotion dan Impulse Buying pada Giant Pekanbaru, Jurnal Tepak Manajemen Bisnis, Vol. VI No. 3 September.

Dian Tauriana dan Ika Fietrin, 2011. Pengaruh Penempatan Produk di Kasir dan Sales Person Terhadap Impulse Buying, Journal The Winners, Vol. 12 No. 1 
Divianto, 2010. Pengaruh Faktor-Faktor In-Store Promotion Terhadap Impulse Buying Decision Pada Konsumen Hypermart PIM, Jurnal Ekonomi dan Informasi Akuntansi (JENIUS), Vol. 3 No. 1, Jan 2013. Duwi Priyatno, Paham Analisis Statistik Data dengan SPSS, Mediakom, Yogyakarta

Husein Umar, 2002Metode Riset Bisnis, Gramedia Pustaka Utama, Jakarta

Imam Ghazali, 2001. Aplikasi Analisis Multivariati dengan Program IBM SPSS, Badan Penerbit Universitas Diponegoro, Semarang

Indra Wahyu Rahmawan, dkk, 2013. Pengaruh Faktor-Faktor Lingkungan Toko Terhadap Pembelian Impulsif (Survei Pada Pengunjung Giant Hypermarket Mall Olympic Garden Kota Malang), Jurnal Administrasi bisnis (JAB), Vol. 6 No. 2 Desember

Indriantoro dan Supomo, 2002. Metodologi Penelitian Bisnis untuk Akuntansi dan Manajemen, BPFE Yogyakarta, Yogyakarta

Ismu Fadli Kharis, 2013. Studi Mengenai Impulse Buying Dalam Penjualan Online (Studi Kasus di Lingkungan Universitas Diponegoro Semarang), Jurnal Diponegoro, Semarang

Nana Herdiana, 2004. Manajemen Bisnis Syariah dan Kewirausahaan, Pustaka Setia, Bandung, 2013. Philip kotler, Manajemen Pemasaran, Alih Bahasa Hendra Teguh, PT. INDEKS, Jakarta

Raeni Dwi Santy, dkk, 2012. Display Toko, Gaya Hidup dan Pembelian Impulsif (Penelitian Pada Konsumen Surf Inc Bandung), Majalah Ilmiah UNIKOM, Vol.11 No. 1

Sugiyono, 2012. Metode Penelitian Bisnis, Alfabeta, Bandung, Cet. Ke 15 , 2005. Statistik untuk Penelitian, Alfabeta, Bandung 